\title{
Review \\ Clinical review: Critical care management of spontaneous intracerebral hemorrhage
}

\author{
Fred Rincon ${ }^{1}$ and Stephan A Mayer ${ }^{2}$
}

\begin{abstract}
${ }^{1}$ Department of Medicine, Cooper University Hospital, The Robert Wood Johnson Medical School University of Medicine and Dentistry of New Jersey, Camden, NJ 08501, USA

${ }^{2}$ Neurological Intensive Care Unit, Division of Stroke and Critical Care, Department of Neurology and the Department of Neurosurgery, College of Physicians and Surgeons (SAM), Columbia University, New York, NY 10032, USA
\end{abstract}

Corresponding author: Stephan A Mayer, sam14@columbia.edu

Published: 10 December 2008

This article is online at http://ccforum.com/content/12/6/237

(c) 2008 BioMed Central Ltd

\begin{abstract}
Intracerebral hemorrhage is by far the most destructive form of stroke. The clinical presentation is characterized by a rapidly deteriorating neurological exam coupled with signs and symptoms of elevated intracranial pressure. The diagnosis is easily established by the use of computed tomography or magnetic resonance imaging. Ventilatory support, blood pressure control, reversal of any preexisting coagulopathy, intracranial pressure monitoring, osmotherapy, fever control, seizure prophylaxis, treatment of hyerglycemia, and nutritional supplementation are the cornerstones of supportive care in the intensive care unit. Dexamethasone and other glucocorticoids should be avoided. Ventricular drainage should be performed urgently in all stuporous or comatose patients with intraventricular blood and acute hydrocephalus. Emergent surgical evacuation or hemicraniectomy should be considered for patients with large $(>3 \mathrm{~cm})$ cerebellar hemorrhages, and in those with large lobar hemorrhages, significant mass effect, and a deteriorating neurological exam. Apart from management in a specialized stroke or neurological intensive care unit, no specific medical therapies have been shown to consistently improve outcome after intracerebral hemorrhage.
\end{abstract}

\section{Introduction}

Intracerebral hemorrhage $(\mathrm{ICH})$ is defined as the spontaneous extravasation of blood into the brain parenchyma. Non-traumatic forms of $\mathrm{ICH}$ account for $10 \%$ to $30 \%$ of all stroke hospital admissions [1], leading to catastrophic disability, morbidity, and a mortality of $30 \%$ to $50 \%$ at 30 days [1]. Death at 1 year varies by different location: $51 \%$ for deep, 57\% for lobar, $42 \%$ for cerebellar and $65 \%$ for brain stem hemorrhages [2]. In a recent population-based study, the overall incidence of $\mathrm{ICH}$ was estimated to be 12 to 15 cases per 100,000 population [3]. The cost of $\mathrm{ICH}$ alone is estimated to be USD $\$ 125,000$ per person per year, with a total cost of USD $\$ 6$ billion per year in the United States alone $[4,5]$ related to both acute and chronic medical care costs, as well as the loss of productivity.

Depending on the underlying cause of hemorrhage, $\mathrm{ICH}$ may be classified as primary when it originates from the spontaneous rupture of small arterioles damaged by chronic hypertension or cerebral amyloid angiopathy, representing at least $85 \%$ of all cases; or secondary when associated with vascular malformations, bleeding related to an ischemic stroke, tumors, abnormal coagulation [6,7], trauma [8], or vasculitis. In approximately $40 \%$ of the cases, blood may also extend into the ventricles - intraventricular hemorrhage (IVH) - potentially leading to neurological death related to acute obstructive hydrocephalus resulting in a substantial worsening of the prognosis.

Despite ongoing attempts to find effective interventions based on the physiopathological understanding of this disease, options are limited, and outcomes remain poor. Evidencebased medical therapies for $\mathrm{ICH}$ are limited to guidelines or options regarding blood pressure (BP) reduction, intracranial pressure (ICP) monitoring, osmotherapy with adequate fluid resuscitation, fever and glycemic control, seizure prophylaxis, and care in a specialized stroke or neurological intensive care unit (ICU) [9]. Recently published guidelines for the management of spontaneous $\mathrm{ICH}$ in adults [2] provide a helpful set of evidence-based recommendations for the management of this form of stroke. This review summarizes current therapeutic options for $\mathrm{ICH}$ based on the American Heart Association Guidelines. A summary of the methods for the classification of the level of evidence is shown in Table 1 [10].

$\mathrm{BP}=$ blood pressure; $\mathrm{CBF}=$ cerebral blood flow; $\mathrm{CPP}=$ cerebral perfusion pressure $\mathrm{CT}=$ computed tomography; $\mathrm{EVD}=$ external ventricular drain; FFP = fresh frozen plasma; GCS = Glasgow Coma Scale; ICH = intracerebral hemorrhage; ICP = intracranial pressure; ICU = intensive care unit; INR = international normalized ratio; IVH = intraventricular hemorrhage; MAP = mean arterial pressure; MRI = magnetic resonance imaging; $\mathrm{NIHSS}=$ National Institute of Health Stroke Scale; $r F V I l a=$ recombinant factor VII; RSI = rapid sequence intubation; t-PA $=$ tissue plasminogen activator. 
Table 1

\section{Definition of classes and levels of evidence used in AHA recommendations}

\begin{tabular}{|c|c|}
\hline Class I & $\begin{array}{l}\text { Conditions for which there is evidence for and/or general agreement that the procedure or treatment is useful and } \\
\text { effective }\end{array}$ \\
\hline Class II & $\begin{array}{l}\text { Conditions for which there is conflicting evidence and/or a divergence of opinion about the usefulness/efficacy of a } \\
\text { procedure or treatment }\end{array}$ \\
\hline Class Ila & Weight of evidence or opinion is in favor of the procedure or treatment \\
\hline Class Ilb & Usefulness/efficacy is less well established by evidence or opinion \\
\hline Class III & $\begin{array}{l}\text { Conditions for which there is evidence and/or general agreement that the procedure or treatment is not } \\
\text { useful/effective and in some cases may be harmful }\end{array}$ \\
\hline Level of Evidence $A$ & Data derived from multiple randomized trials \\
\hline Level of Evidence B & Data derived from a single randomized trial or non-randomized trials \\
\hline Level of Evidence $\mathrm{C}$ & Expert Opinion or case studies \\
\hline
\end{tabular}

From [10].

\section{Risk factors}

Hypertension is the most important and prevalent risk factor for $\mathrm{ICH}$ [11]. In a study of 331 patients, hypertension increased the risk of $\mathrm{ICH}$ by more than two-fold, especially in patients younger than 55 years of age who stopped anti-hypertensive treatment [12]. Hypertension causes a chronic small-vessel vasculopathy characterized by fragmentation, degeneration, and the eventual rupture of small penetrating vessels within the brain (lipohyalinosis) [13]. Commonly affected structures include the basal ganglia and thalamus (50\%), lobar regions (33\%), and brainstem and cerebellum (17\%) $[6,14]$.

Low cholesterol levels have been implicated as a risk factor for primary $\mathrm{ICH}$. There is controversy regarding this association as the results from case-control and cohort studies have suggested that lower cholesterol levels imparted an increased risk of $\mathrm{ICH}$ [15-17]. The results of additional cohort-studies [18] and recent cardiac trials that have evaluated the effects of statin therapy have failed to confirm this association [19]. However, the more recent results of the Stroke Prevention by Aggressive Reduction in Cholesterol Levels Study (SPARCL) showed that in patients with recent stroke or transient ischemic attack, $80 \mathrm{mg}$ of atorvastatin per day reduced the overall incidence of strokes and of cardiovascular events for over 5 years, despite a small increase in the incidence of hemorrhagic stroke [20].

Heavy alcohol intake has been implicated as a risk factor for $\mathrm{ICH}$ in recent case-control studies [21-25]. This effect may be mediated in part by hypertension, but those studies that controlled for it have supported an independent association. In theory, alcohol may affect platelet function, coagulation physiology, and enhance vascular fragility [23].

Cigarette smoking has not been linked to an increased risk of $\mathrm{ICH}$. However, a retrospective study found that smokers with hypertension have an increased risk of $\mathrm{ICH}$ [12], an effect that is mediated by hypertension and not by tobacco abuse per se. Similarly, ICH may be a complication of incidental or chronic cocaine use [26-28].

Non-modifiable risk factors for $\mathrm{ICH}$ include advanced age $[29,30]$, male gender, and African-American or Japanese race/ethnicity [28,31]. Cerebral amyloid angiopathy is an important risk factor for $\mathrm{ICH}$ in the elderly. It is characterized by the deposition of $\beta$-amyloid protein in small- to mediumsized blood vessels of the brain and leptomeninges, which may undergo fibrinoid necrosis. It can occur as a sporadic disorder, in association with Alzheimer's disease, or with certain familial syndromes (apolipoprotein $\varepsilon 2$ and $\varepsilon 4$ allele) [7].

\section{Initial approach \\ Diagnosis}

Widespread use of non-enhancing computed tomography (CT) scan of the brain has dramatically changed the diagnostic approach of this disease, making it the method of choice to evaluate the presence of ICH (Figure 1). CT scan evaluates the size and location of the hematoma, extension into the ventricular system, degree of surrounding edema, and anatomical disruption (Class I, Level of Evidence A). Hematoma volume may be easily calculated from CT scan images by use of the $A B C \div 2$ method, a derived formula from the calculation of the volume of the sphere [32,33].

CT-angiography is not routinely performed in most centers, but may prove helpful in predicting hematoma expansion and outcomes [34,35]. In a recent prospective study of 39 patients with spontaneous $\mathrm{ICH}$, focal enhancing foci (contrast extravasation, 'spot sign') seen in initial CT-angiography were associated with the presence and extent of hematoma progression with good sensitivity (91\%) and negative predictive value (96\%) (Figure 2) [36]. Magnetic resonance imaging (MRI) techniques, such as gradient-echo (GRE, T2*), are highly sensitive for the diagnosis of $\mathrm{ICH}$ as well. Sensi- 
Figure 1

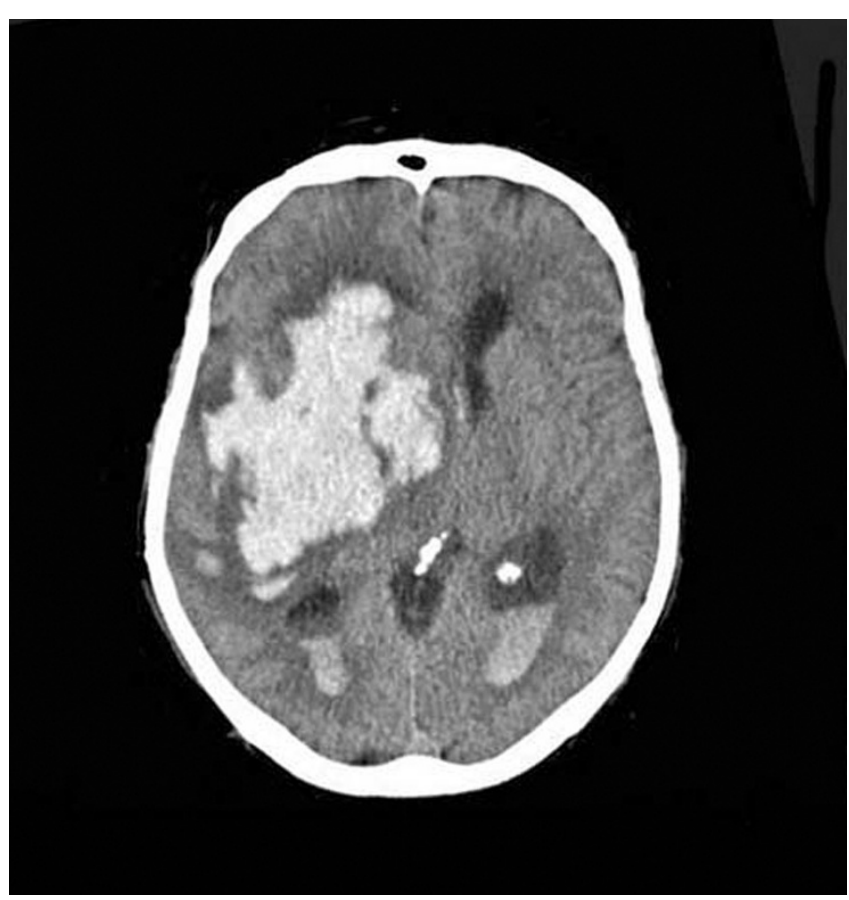

Computed tomography scan of patient with intracerebral hemorrhage.

tivity of MRI for $\mathrm{ICH}$ is $100 \%$. In the HEME Study, MRI and CT were equivalent for the detection of acute ICH but MRI was significantly more accurate than $\mathrm{CT}$ for the detection of chronic ICH [37].

Conventional diagnostic cerebral angiography should be reserved for patients in whom secondary causes of $\mathrm{ICH}$ are suspected, such as aneurysms, arteriovenous malformations, cortical vein or dural sinus thrombosis, or vasculitis. Findings on CT scan or MRI that should prompt angiographic study include the presence of subarachnoid hemorrhage, IVH, underlying calcification, or lobar hemorrhage in nonhypertensive younger patients. The role of angiography after $\mathrm{ICH}$ has been addressed by two studies. Zhu and colleagues [38] reported abnormalities on angiography in $48 \%$ of patients who were normotensive and younger than 45 years of age, $49 \%$ of patients with lobar hemorrhages, $65 \%$ with isolated IVH, and no abnormalities in patients older than 45 years who had a history of hypertension with subcortical $\mathrm{ICH}$. In a second study, Halpin and colleagues [39] reported finding an underlying lesion in $84 \%$ of patients that appeared to have a structural abnormality seen previously on brain imaging. Diagnostic catheter angiography should be strongly considered in all patients with primary IVH and younger nonhypertensive patients with lobar $\mathrm{ICH}$.

\section{Airway control, breathing, and circulation}

Rapid neurological deterioration and ensuing loss of consciousness with impairment of reflexes that maintain the airway mandate permanent airway control (Figure 3) [40] (Class I, Level of Evidence B). Failure to recognize imminent airway loss may result in complications, such as aspiration, hypoxemia, and hypercapnia. Preferred induction agents for rapid sequence intubation (RSI) in the setting of $\mathrm{ICH}$ include propofol [41] and etomidate [42] (Table 2), both of which are short-acting agents that will not obscure the neurological exam for a prolonged period of time (Class IIA, Level of Evidence B). Adverse effects of propofol include druginduced hypotension that usually responds to fluid infusion [42]. Adverse effects of etomidate include nausea, vomiting, myoclonic movements, lowering of seizure threshold [42], and adrenal suppression [43]. Unfavorable effects on the ICP have been reported with the use of midazolam $[41,44]$. In certain circumstances, neuromuscular paralysis may be needed as part of RSI. Succinylcholine is the most commonly administered muscle relaxant for RSI, owing to its rapidity of onset (30 to $60 \mathrm{~s}$ ) and short duration (5 to 15 minutes) [45]. However, side effects of succinylcholine include hyperkalemia, cardiac arrhythmias, exacerbation of neuropathy or myopathy, malignant hyperthermia, and elevation of intracranial pressure in patients with intracranial mass lesions $[42,46]$. For this reason, in neurological patients, non-depolarizing neuromuscular blocking agents, such as cisatracurium [47], rocuronium [42], or vecuronium, are preferred [48] (Class IIA, Level of Evidence B). In patients with increased ICP, premedication with intravenous lidocaine for $\mathrm{RSI}$ is of questionable use [49].

Isotonic fluid resuscitation and vasopressors are indicated for patients in shock [2]. Dextrose-containing solutions should be avoided as hyperglycemia may be detrimental to the injured brain [50] (Class III, Level of Evidence C). Additionally, a thorough laboratory panel should be obtained, including hematological, biochemical, coagulation profiles, echocradiogram and chest $\mathrm{X}$-rays.

\section{Blood pressure control}

Extreme levels of BP after $\mathrm{ICH}$ should be aggressively but carefully treated to reduce the risk of hematoma expansion and to keep and maintain cerebral perfusion pressure (CPP; $\mathrm{CPP}=$ mean arterial pressure (MAP) - ICP). Controversy exists about the initial treatment of high BP in patients with $\mathrm{ICH}$. An expanding hematoma may result from persistent bleeding and/or re-bleeding from a single arteriolar rupture. Some studies have reported evidence of hematoma growth from bleeding into an ischemic penumbra zone surrounding the hematoma [51,52] but other reports have not confirmed the existence of ischemia at the hypoperfused area in the periphery of the hematoma.

In the study by Brott and colleagues [53], no association was demonstrated between hematoma growth and levels of BP, but the use of anti-hypertensive agents may have negatively confounded this association. Similarly, initial BP was not associated with hematoma growth in the Recombinant 


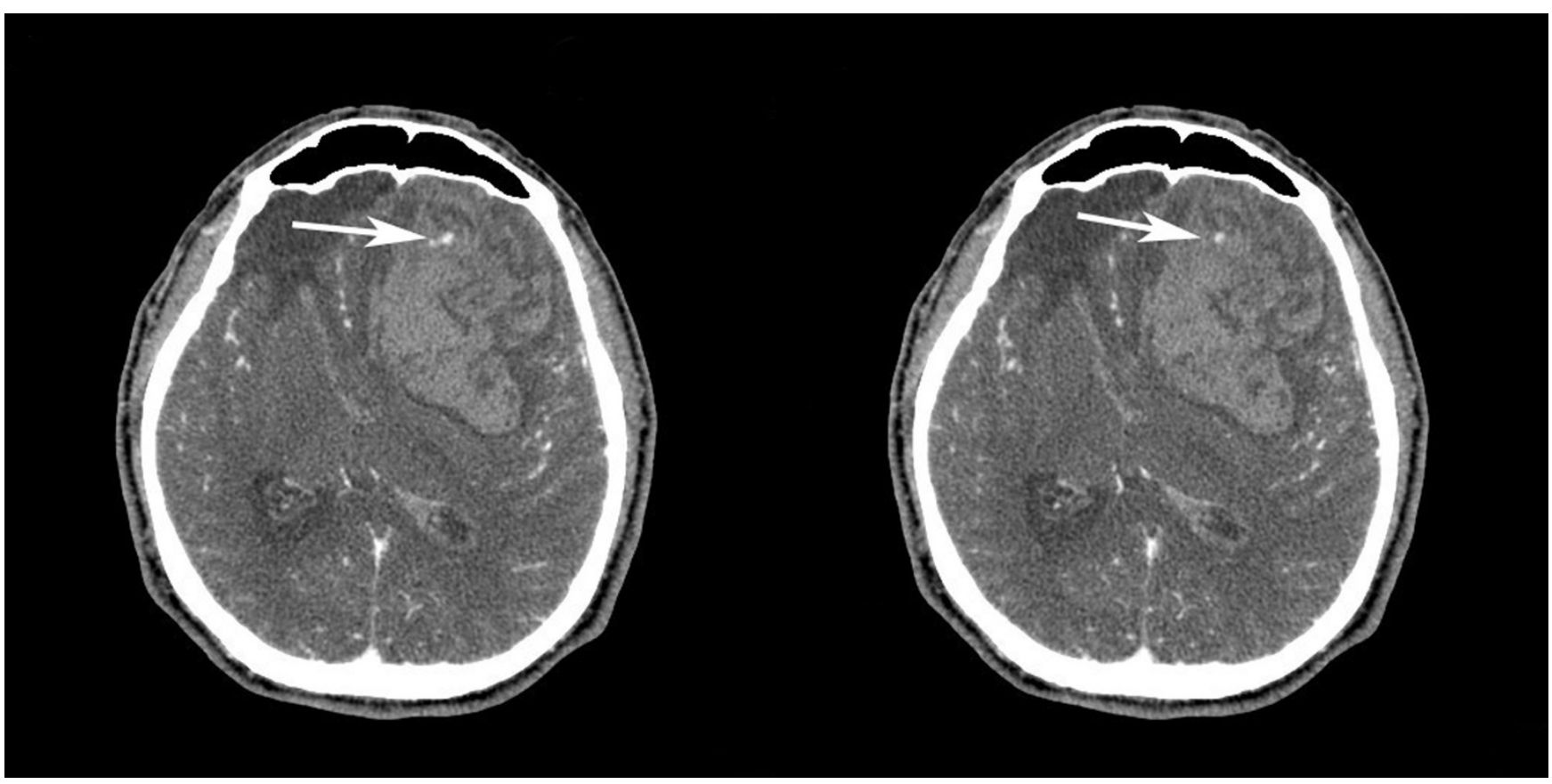

Contrast extravasation seen in the hematoma of a patient with acute coagulopathic intracerebral hemorrhage (white arrows).

Activated Factor VII ICH Trial [54]. Moreover, aggressive blood pressure reduction after $\mathrm{ICH}$ may predispose to an abrupt drop in CPP and ischemia, which, in turn, may be accompanied by elevations of ICP and further neurological damage. In a recent pilot trial of $\mathrm{BP}$ reduction after $\mathrm{ICH}, 14$ patients with supratentorial $\mathrm{ICH}$ were randomized to receive either labetalol or nicardipine within 22 hours of onset to lower the MAP by $15 \%$. Cerebral blood flow (CBF) studies were performed before and after treatment with positron emission tomography and $\left.{ }^{15} \mathrm{O}\right]$ water. No changes in global or peri-hematoma CBF were observed [55]. Two additional studies have demonstrated that a controlled, pharmacologically based reduction in BP has no adverse effects on CBF in humans or animals [56,57]. BP level has been correlated with increases in the ICP and volume of the hematoma but it has been very difficult to explain if hypertension is the cause of hematoma growth or if this is just a response to elevated $\mathrm{ICP}$ in the setting of large volume $\mathrm{ICH}$ to maintain cerebral perfusion.

In general, the American Heart Association Guidelines indicate that systolic blood pressures exceeding $180 \mathrm{mmHg}$ or MAP exceeding $130 \mathrm{mmHg}$ should be managed with continuous infusion antihypertensive agents such as labetalol, esmolol, or nicardipine [2] (Class IIB, Level of Evidence C). Urapidil, a sympatholytic agent with vasodilator properties is an alternative but it is currently not approved for use in the US. Use of nitroprusside has drawbacks since this agent may exacerbate cerebral edema and intracranial pressure [58].
Oral and sub-lingual agents are not preferred, because of the need for immediate and precise BP control. There are few, if any, comparative or randomized trials providing definitive conclusions about the efficacy and safety of comparative agents.

In comatose patients, it is recommended to monitor ICP and to titrate vasopressors to maintain CPP in the range 70 to $90 \mathrm{mmHg}$. Use of brain tissue oxygen and thermodilution CBF probes to detect reductions in perfusion related to excessive lowering of BP is gaining in popularity. In general, no matter how high the BP is, the MAP should not be reduced beyond $15 \%$ to $30 \%$ over the first 24 hours [56]. In the setting of impaired blood flow autoregulation, excessive blood pressure reduction may exacerbate ischemia in the area surrounding the hematoma and worsen perihematomal brain injury $[59,60]$ (Table 2; Figure 3). In fact transcranial doppler velocities become positively correlated with CPP when CPP drops below the left side of the autoregulation curve [61].

Whether more aggressive BP reduction after $\mathrm{ICH}$ is safe is the matter of the ongoing National Institute of Neurological Diseases and Stroke supported Antihypertensive Treatment in Acute Cerebral Hemorrhage (ATACH) pilot study [62]. Additionally, the ongoing phase III Intensive Blood Pressure Reduction in Acute Cerebral Hemorrhage Trial (INTERACT) will test the hypothesis that lowering BP acutely after $\mathrm{ICH}$ will reduce the chances of dying or surviving with long-term disability [63]. 
Table 2

\begin{tabular}{|c|c|c|c|}
\hline Drug & Mechanism & Dose & Cautions \\
\hline Labetalol & $\begin{array}{l}\text { Alpha- } 1 \text {, beta- } 1 \text {, beta- } 2 \text { receptor } \\
\text { antagonist }\end{array}$ & $\begin{array}{l}20-80 \mathrm{mg} \text { bolus every } 10 \text { minutes, } \\
\text { up to } 300 \mathrm{mg} ; 0.5 \text { to } 2.0 \mathrm{mg} / \text { minute } \\
\text { infusion }\end{array}$ & $\begin{array}{l}\text { Bradycardia, congestive heart failure, } \\
\text { bronchospasm, hypotension }\end{array}$ \\
\hline Esmolol & Beta-1 receptor antagonist & $\begin{array}{l}0.5 \mathrm{mg} / \mathrm{kg} \text { bolus; } \\
50 \text { to } 300 \mu \mathrm{g} / \mathrm{kg} / \mathrm{minute}\end{array}$ & $\begin{array}{l}\text { Bradycardia, congestive heart failure, } \\
\text { bronchospasm }\end{array}$ \\
\hline Nicardipine & $\begin{array}{l}\text { L-type calcium channel blocker } \\
\text { (dihydropyridine) }\end{array}$ & 5 to $15 \mathrm{mg} / \mathrm{h}$ infusion & $\begin{array}{l}\text { Severe aortic stenosis, myocardial } \\
\text { ischemia, hypotension }\end{array}$ \\
\hline Enalaprilat & ACE inhibitor & $\begin{array}{l}0.625 \mathrm{mg} \text { bolus; } 1.25 \text { to } 5 \mathrm{mg} \\
\text { every } 6 \mathrm{~h}\end{array}$ & $\begin{array}{l}\text { Variable response, precipitous fall in blood } \\
\text { pressure with high-renin states }\end{array}$ \\
\hline Fenoldopam & Dopamine-1 receptor agonist & 0.1 to $0.3 \mu \mathrm{g} / \mathrm{kg} / \mathrm{minute}$ & $\begin{array}{l}\text { Tachycardia, headache, nausea, flushing, } \\
\text { glaucoma, portal hypertension }\end{array}$ \\
\hline Nitroprusside* & Nitrovasodilator (arterial and venous) & 0.25 to $10 \mu \mathrm{g} / \mathrm{kg} /$ minute & $\begin{array}{l}\text { Increased intracranial pressure, variable } \\
\text { response, myocardial ischemia, } \\
\text { thiocyanate and cyanide toxicity, } \\
\text { hypotension }\end{array}$ \\
\hline
\end{tabular}

*Nitroprusside is not recommended for use in acute intracerebral hemorrhage because of its tendency to increase intracranial pressure. Modified with permission from Mayer SA, Rincon F: Management of intracerebral hemorrhage. Lancet Neuro/ 2005, 4:662-672. ACE, angiotensinconverting enzyme.

\section{Figure 3}

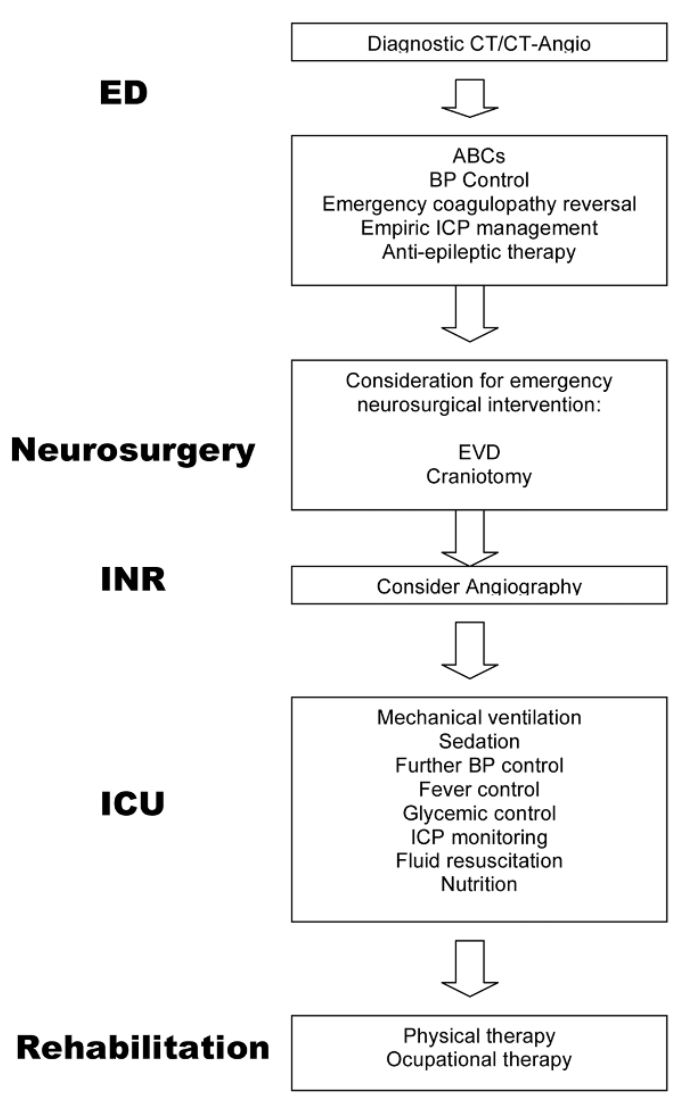

Approach to intracerebral hemorrhage from the emergency department to the intensive care unit.
Though no prospective study has addressed the timing of conversion from intravenous to oral anti-hypertensive management, this process can generally be started after 24 to 72 hours, as long as the patient's condition has stabilized [6].

Initial emergency intracranial pressure management

Emergency measures for ICP control are appropriate for stuporous or comatose patients, or those who present acutely with clinical signs of brain stem herniation (that is, pupillary abnormalities or motor posturing; Figure 3). The head should be elevated to 30 degrees, 1.0 to $1.5 \mathrm{~g} / \mathrm{kg}$ of $20 \%$ mannitol should be administered by a rapid infusion, and the patient should be hyperventilated to a $\mathrm{pCO}_{2}$ of 26 to $30 \mathrm{mmHg}$ (Class IIA, Level of Evidence B). As a second line therapy, or if the patient is relatively hypotensive, 0.5 to $2.0 \mathrm{ml} / \mathrm{kg}$ of $23.4 \%$ saline solution can be administered through a central venous line [64] (Class IIA, Level of Evidence B). These measures are designed to lower ICP as quickly and effectively as possible, in order to 'buy time' before a definitive neurosurgical procedure (craniotomy, ventriculostomy (Class IIA, Level of Evidence B), or placement of an ICP monitor) can be performed (Table 3). Corticosteroids are contraindicated based on the results of randomized trials that have failed to demonstrate their efficacy in ICH [65,66] (Class III, Level of Evidence B). Neurosurgical consultation is warranted for those patients with rapidly declining mental status and hydrocephalus with IVH seen in the initial CT scan. Early placement of a ventricular drain in this case may be life-saving [67] (Class IIA, Level of Evidence B; Figure 3).

\section{Hemostatic therapy}

Hematoma size is an important determinant of mortality after $\mathrm{ICH}$ and early hematoma growth, which is the increase in 
Table 3

Stepwise treatment protocol for elevated intracranial pressure* in a monitored patient in the intensive care unit

1. Surgical decompression

2. Sedation

3. CPP optimization

4. Osmotherapy

5. Controlled hyperventilation

6. High dose pentobarbital therapy

7. Hypothermia
Consider repeat CT scanning, and definitive surgical intervention or ventricular drainage

Intravenous sedation to attain a motionless, quiet state

Vasopressor infusion if CPP is $<70 \mathrm{mmHg}$, or reduction of blood pressure if CPP is $>110 \mathrm{mmHg}$ (preferred agents are phenylephrine, vasopressin, nor-epinephrine)

Mannitol 0.25 to $1.5 \mathrm{~g} / \mathrm{kg} \mathrm{IV}$ or 0.5 to $2.0 \mathrm{ml} / \mathrm{kg} 23.4 \%$ hypertonic saline (repeat every 1 to 6 hours as needed)

Target $\mathrm{PaCO}_{2}$ levels of 26 to $30 \mathrm{mmHg}$

Load with 5 to $20 \mathrm{mg} / \mathrm{kg}$, infuse 1 to $4 \mathrm{mg} / \mathrm{kg} / \mathrm{h}$

Cool core body temperature to 32 to $33^{\circ} \mathrm{C}$

*Elevated intracranial pressure $\geq 20 \mathrm{mmHg}$. Adapted from Mayer SA, Chong J: Critical care management of increased intracranial pressure. $J$ Int Care Med 2002, 17:55-67. CPP, cerebral perfusion pressure; CT, computed tomography; IV, intravenous; $\mathrm{PaCO}_{2}=$ arterial partial pressure of carbon dioxide.

hematoma size within 6 hours after onset, is consistently associated with poor clinical outcomes [53,68-70] and an increased mortality rate [70]. As a corollary, hematoma growth occurs in only $5 \%$ of patients who are initially scanned beyond 6 hours of symptom onset. Similarly, significantly greater reductions in the Glasgow Coma Scale (GCS) and National Institute of Health Stroke Scale (NIHSS) have been reported among patients with documented hematoma growth on 1-hour follow-up CT scans, versus those without growth [53]. These observations suggest that the reduction in hematoma growth may be an important strategy for improvement of survival and outcome after $\mathrm{ICH}$.

To be effective, hematostatic therapy must be given early after the onset of $\mathrm{ICH}$. Even if a hemostatic intervention is completely effective, substantial hematoma enlargement (that is, a $>33 \%$ increase from baseline) would be expected to occur in $10 \%, 17 \%$ and $21 \%$ of patients after a $15-, 30-$, or 45-minute treatment delay following the baseline scan [53]. Underlying this principle is the fact that the only consistently identified predictor of early hematoma growth is the interval from the onset of symptoms to CT: the earlier the first scan is obtained, the more likely subsequent bleeding will be detected on a follow-up scan $[53,69,70]$. Importantly, hematoma growth occurs in only $5 \%$ of patients who are initially scanned beyond 6 hours of symptom onset $[53,69,70]$.

Recombinant factor VII ( $r F V I l a$, Novoseven ${ }^{\circledR}$, Novo Nordisk) is a powerful initiator of hemostasis that is currently approved for the treatment of bleeding in patients with hemophilia who are resistant to factor VIII replacement therapy. Considerable evidence exists suggesting that rFVlla may enhance hemostasis in patients with normal coagulation systems as well. In a randomized, double blind, placebo controlled study, 399 patients with spontaneous $\mathrm{ICH}$ received treatment with $\mathrm{rFVIIa}$ at doses of 40,80 , or $160 \mu \mathrm{g} / \mathrm{kg}$ within 4 hours after $\mathrm{ICH}$ onset. The primary outcome of the study was change in hematoma volume at 24 hours, a direct measure of hematoma growth. Secondary outcomes included clinical outcome at three months as measured by Modified Ranking Scale, Barthel Index, Extended GCS and NIHSS. Use of rFVIla was associated with a $38 \%$ reduction in mortality and significantly improved functional outcomes at 90 days, despite a $5 \%$ increase in the frequency of arterial thromboembolic adverse events [71]. A similar pilot trial of epsilon aminocaproic acid, an anti-fibrinolytic agent, has been conducted with negative results [72].

In May of 2008, the results of the phase III Factor VIla for Acute Hemorrhagic Stroke Trial (FAST) were published. This study compared doses of 80 and $20 \mu \mathrm{g} / \mathrm{kg}$ of $\mathrm{rFVlla}$ with placebo in an overall trial population of 841 patients. No significant difference was found in the main outcome measure, which was the proportion of patients suffering death or with severe disability according to the modified Rankin scale at 90 days (score of 5 or 6 ) but the hemostatic effect and side effect profiles were confirmed [73]. On the basis of these results, routine use of rFVIla as a hemostatic therapy for all patients with $\mathrm{ICH}$ within a 4-hour time window cannot be recommended (Class III, Level of Evidence B). Future studies to test rFVIla in younger patients who present within an earlier time-frame are needed.

\section{Reversal of anticoagulation}

Anticoagulation with warfarin increases the risk of $\mathrm{ICH}$ by 5 to 10-fold in the general population [74], and approximately $15 \%$ of $\mathrm{ICH}$ cases overall are associated with its use. Among $\mathrm{ICH}$ patients, warfarin increases the risk of progressive bleeding and clinical deterioration, and doubles the risk of mortality [75]. Failure to rapidly normalize the international normalized ratio (INR) to below 1.4 further increases these risks [76]. Patients with $\mathrm{ICH}$ receiving warfarin should be reversed immediately with fresh frozen plasma (FFP; Class IIB, Level of Evidence B) or prothrombin-complex concentrate $[77,78]$ (Class IIB, Level of Evidence B), and vitamin K (Class I, Level of Evidence B) [79] (Table 4). Treatment should never 
be delayed in order to check coagulation tests. Unfortunately, normalization of the INR with this approach usually takes several hours, and clinical results are often poor. The associated volume load with FFP may also cause congestive heat failure in the setting of cardiac or renal disease. Prothrombin complex concentrate contains vitamin K-dependent coagulation factors II, VII, IX, and X, normalizes the INR more rapidly than FFP, and can be given in smaller volumes, but carries a higher risk for developing disseminated intravascular coagulation [76].

Recent reports have described the use of rFVlla to speed the reversal of warfarin anticoagulation in $\mathrm{ICH}$ patients [80]. A single intravenous dose of rFVlla can normalize the INR within minutes, with larger doses producing a longer duration of effect, a response seen in healthy volunteers [81]. Doses of rFVIla ranging from 10 to $90 \mu \mathrm{g} / \mathrm{kg}$ have been used to reverse the effects of warfarin in acute $\mathrm{ICH}$ in order to expedite acute neurosurgical interventions with good clinical results (Class IIB, Level of Evidence C) $[80,82]$. When this approach is used, rFVlla should be used as an adjunct to coagulation factor replacement and vitamin $\mathrm{K}$, since its effect lasts only several hours. Patients with $\mathrm{ICH}$ who have been anticoagulated with unfractionated or low-molecular weight heparin should be reversed with protamine sulfate [83] (Class I, Level of Evidence B) and patients with thrombocytopenia or platelet dysfunction can be treated with a single dose of desmopressin, platelet transfusions, or both [84] (Class IIB, Level of Evidence C) (Table 4). Re-starting anticoagulation in patients with a strong indication, such as a mechanical heart valve or atrial fibrillation with a history of cardioembolic stroke, can be safely implemented after 10 days [85].

\section{Intensive care unit management}

Observation in an ICU or similar setting is strongly recommended for at least the first 24 hours after ictus (Class I, Level of Evidence B), since the risk of neurological deterioration is highest during this period [86] and because the majority of patients with brain stem or cerebellar hemorrhage have depressed levels of consciousness requiring ventilatory support [40] (Figure 3). Measurements in the ICU indicated for the optimal cardiovascular monitoring of $\mathrm{ICH}$ patients include invasive arterial blood pressure, central venous pressure, and, if required, pulmonary artery catheter monitoring. An external ventricular drain should be placed in patients with a depressed level of consciousness (GCS score $\leq 8$ ), signs of acute hydrocephalus or intracranial mass effect on CT, and a prognosis that warrants aggressive ICU care [87].

Outcomes after $\mathrm{ICH}$ are better when patients are cared for in specialized ICUs. In a large administrative database, Diringer and colleagues [88] demonstrated that mortality after $\mathrm{ICH}$ was associated with lower GCS scores, higher age, and admission to a general medical-surgical, as opposed to specialty neurological, ICU. In this study a clear impact on outcomes was seen when patients were admitted and cared for by a specialized neurocritical care team. Similarly, in the study by Mirski and colleagues [89], mortality and disposition at discharge in $\mathrm{ICH}$ patients treated in a neuro-ICU compared to a similar cohort treated 2 years earlier in a general ICU setting. Although the exact reason why improved outcomes occur with treatment in a dedicated neuro-ICU remains unclear, much attention has focused recently on the major role that therapeutic nihilism and self-fulfilling prophesies of doom can have in determining outcome after $\mathrm{ICH}[90,91]$.

\section{Patient positioning}

To minimize ICP and reduce the risk of ventilator-associated pneumonia in mechanically ventilated patients, the head should be elevated 30 degrees (Class IIA, Level of Evidence B). In mechanically ventilated patients, further need for head elevation should be guided by changing of pulmonary and volume needs.

\section{Fluids}

Isotonic fluids such as $0.9 \%$ saline at a rate of approximately $1 \mathrm{ml} / \mathrm{kg} / \mathrm{h}$ should be given as the standard intravenous replacement fluid for patients with $\mathrm{ICH}$ and optimized to achieve euvolemic balance and an hourly diuresis of $>0.5 \mathrm{cc} / \mathrm{kg}$ (Class I, Level of Evidence B). Free water given in the form of $0.45 \%$ saline or $5 \%$ dextrose in water can exacerbate cerebral edema and increase ICP because it flows down its osmotic gradient into injured brain tissue (Class III, Level of Evidence C) [50]. Systemic hypo-osmolality ( $<280 \mathrm{mOsm} / \mathrm{L}$ ) should be aggressively treated with mannitol or $3 \%$ hypertonic saline (Class IIA, Level of Evidence B). A state of euvolemia should be maintained by monitoring fluid balance and body weight, and by maintaining a normal central venous pressure (range 5 to $8 \mathrm{mmHg}$ ). Careful interpretation of the central venous pressure should be done when analyzing its value in the setting of positive end-expiratory pressure (PEEP).

The use of hypertonic saline in the form of a $2 \%$ or $3 \%$ sodium/chloride-acetate solution $(1 \mathrm{ml} / \mathrm{kg} / \mathrm{h})$ has become an increasingly popular alternative to normal saline as a resuscitation fluid for patients with significant perihematomal edema and mass effect after ICH (Class IIA, Level of Evidence B). The goal is to establish and maintain a baseline state of hyperosmolality (300 to $320 \mathrm{mOsms} / \mathrm{L}$ ) and hypernatremia (150 to $155 \mathrm{mEq} / \mathrm{L})$, which may reduce cellular swelling and the number of ICP crises. Potential complications of hypertonic saline use are fluid overload, pulmonary edema, hypokalemia, cardiac arrhythmias, hyperchloremic metabolic acidosis, and dilutional coagulopathy, [92]. Hypertonic saline should be gradually tapered and the serum sodium level should never be allowed to drop more than $12 \mathrm{mEq} / \mathrm{L}$ over 24 hours, to avoid rebound cerebral edema and increased ICP [92,93].

\section{Prevention of seizures}

Acute seizures should be treated with intravenous lorazepam ( 0.05 to $0.1 \mathrm{mg} / \mathrm{kg}$ ) followed by a loading dose of phenytoin 
Table 4

\begin{tabular}{|c|c|c|c|c|}
\hline Scenario & Agent & Dose & Comments & $\begin{array}{l}\text { Level of } \\
\text { Evidence* }\end{array}$ \\
\hline \multirow[t]{5}{*}{ Warfarin } & Fresh frozen plasma & $15 \mathrm{ml} / \mathrm{kg}$ & Usually 4 to 6 units $(200 \mathrm{ml})$ each are given & $\mathrm{B}$ \\
\hline & or & & & \\
\hline & $\begin{array}{l}\text { Prothrombin complex } \\
\text { concentrate }\end{array}$ & 15 to $30 \mathrm{U} / \mathrm{kg}$ & $\begin{array}{l}\text { Works faster than fresh frozen plasma, but carries } \\
\text { risk of disseminated intravascular coagulation }\end{array}$ & $\mathrm{B}$ \\
\hline & and & & & \\
\hline & Intravenous vitamin $\mathrm{K}$ & $10 \mathrm{mg}$ & $\begin{array}{l}\text { Can take up to } 24 \text { hours to normalize international } \\
\text { normalized ratio }\end{array}$ & $\mathrm{B}$ \\
\hline $\begin{array}{l}\text { Warfarin and emergency } \\
\text { neurosurgical intervention }\end{array}$ & Above plus rFVlla & 20 to $80 \mu \mathrm{g} / \mathrm{kg}$ & Contraindicated in acute thromboembolic disease & $\mathrm{C}$ \\
\hline $\begin{array}{l}\text { Unfractionated or } \\
\text { low molecular weight } \\
\text { heparin }\end{array}$ & Protamine sulfate & $\begin{array}{l}1 \mathrm{mg} \text { per } 100 \text { units } \\
\text { of heparin, or } \\
1 \mathrm{mg} \text { of enoxaparin }\end{array}$ & $\begin{array}{l}\text { Can cause flushing, bradycardia, or hypotension, } \\
\text { anticoagulation }\end{array}$ & $\mathrm{C}$ \\
\hline \multirow[t]{3}{*}{$\begin{array}{l}\text { Platelet dysfunction } \\
\text { or thrombocytopenia }\end{array}$} & Platelet transfusion & 6 units & $\begin{array}{l}\text { Range } 4 \text { to } 8 \text { units based on size; } \\
\text { transfuse to }>100,000\end{array}$ & $\mathrm{C}$ \\
\hline & and/or & & & \\
\hline & Desmopressin (DDAVP) & $0.3 \mu \mathrm{g} / \mathrm{kg}$ & Single dose required & $\mathrm{C}$ \\
\hline
\end{tabular}

* See Table 1 for descriptions of Levels of Evidence. ${ }^{\dagger}$ Protamine has minimal efficacy against danaparoid or fondaparinux. Reproduced with permission from Mayer SA, Rincon F: Management of intracerebral hemorrhage. Lancet Neuro/ 2005, 4:662-672. rFVIlla, recombinant factor VII.

or fosphenytoin $(20 \mathrm{mg} / \mathrm{kg}$ ) (Class I, Level of Evidence B; Figure 3). An alternative to phenytoin infusion is levetiracetam (500 mg q12h, adjusted for renal insufficiency). Side effects of phenytin infusions include rash, hypotension, arrhythmias, and severe hypocalcemia for the phosphenytoin presentation. Patients with $\mathrm{ICH}$ may benefit from prophylactic anti-epileptic drug therapy, but no randomized trial has addressed the efficacy of this approach. The American Heart Association Guidelines have recommended anti-epileptic medication for up to one month, after which therapy should be discontinued in the absence of seizures [94]. This recommendation is supported by the results of a recent study that showed that the risk of early seizures was reduced by prophylactic antiepileptic drug therapy [95]. The 30-day risk for convulsive seizures after $\mathrm{ICH}$ is approximately $8 \%$, and the risk of overt status epilepticus is $1 \%$ to $2 \%$ [95]. Lobar location and small hematomas are independent predictors of early seizures [95]. The argument for prophylactic anticonvulsant therapy in stuporous or comatose $\mathrm{ICH}$ patients is bolstered by the fact that continuous electroencephalogram monitoring demonstrates electrographic seizure activity in approximately $25 \%$ of these patients, despite prophylactic anti-epileptic drug therapy $[96,97]$. The risk of late seizures or epilepsy among survivors of $\mathrm{ICH}$ is $5 \%$ to $27 \%$ [95].

\section{Temperature control}

Fever (temperature $>38.3^{\circ} \mathrm{C}$ ) after $\mathrm{ICH}$ is common, particularly with IVH [98], and should be treated aggressively (Figure 3; Class I, Level of Evidence C). Sustained fever after
$\mathrm{ICH}$ has been shown to be independently associated with poor outcome after $\mathrm{ICH}$ [99]. A large body of experimental evidence indicates that even small degrees of hyperthermia can worsen ischemic brain injury by exacerbating excitotoxic neurotransmitter release, proteolysis, free radical and cytokine production, blood-brain barrier compromise, and apoptosis $[100,101]$. Brain temperature elevations have also been associated with hyperemia, exacerbation of cerebral edema, and elevated intracranial pressure [102,103].

As a general standard, acetaminophen and cooling blankets are recommended for almost all patients with sustained fever in excess of $38.3^{\circ} \mathrm{C}\left(101.0^{\circ} \mathrm{F}\right)$, despite the lack of prospective randomized controlled trials supporting this approach [104,105]. Acetaminophen should be used with caution in patients with hepatic dysfunction. Newer adhesive surface cooling systems and endovascular heat exchange catheters have been shown to be much more effective for maintaining normothermia [106,107]; however, it remains to be seen if these measures can improve clinical outcome.

\section{Management of hyperglycemia}

Admission hyperglycemia is a potent predictor of 30-day mortality in both diabetic and non-diabetic patients with $\mathrm{ICH}$ [108]. The detrimental effect of hyperglycemia has been well studied in acute vascular syndromes. In ischemic stroke, hyperglycemia occurs in $20 \%$ to $40 \%$ of patients and is associated with infarct expansion, worse functional outcome, longer hospital stays, higher medical costs, and an increased 
risk of death [109-111] and it is felt to be secondary to a catecholamine surge and generalized stress response [110].

In the critically ill population, hyperglycemia seems much more acutely toxic than in healthy individuals, for whom cells can protect themselves by down-regulation of glucose transporters [112]. The acute toxicity of high levels of glucose in critical illness might be explained by an accelerated cellular glucose overload and more pronounced toxic side effects of glycolysis and oxidative phosphorylation [113]. Neurons and several other cell types are insulin independent for glucose uptake, which is mediated by transporters such as GLUT-1, GLUT-2, and GLUT-3 [114]. These transporters are up-regulated by hypoxia and inflammatory mediators such as angiotensin-II, endothelin-1, vascular endothelial growth factor, and transforming growth factor- $\beta$ among others. These transporters facilitate glucose entry into the neuron where intracellular hyperglycemia can lead to oxidative stress and exaggerated production of superoxide species [114]. Peroxynitrite, superoxide, and other reactive oxygen species lead to inhibition of the glycolytic enzyme glyceraldhyde phosphate dehydrogenase and mitochondrial complexes I and IV, the basis of mitochondrial dysfunction likely to induce end-organ failure and cellular death [114].

Strict glucose control after ICH is recommended (Class IIA, Level of Evidence C). This approach has been linked to reductions in intracranial pressure, duration of mechanical ventilation, and seizures in an heterogeneous cohort of critically ill patients [115].

\section{Elevated intracranial pressure management}

Large volume $\mathrm{ICH}$ carries the risk of developing cerebral edema and high ICP $\left(\geq 15 \mathrm{mmHg}\right.$ or $\left.\geq 20 \mathrm{mmH}_{2} \mathrm{O}\right)$, and the presence of IVH further increases the risk of mortality $[116,117]$ (Figure 3). This effect is primarily related to the development of obstructive hydrocephalus and alterations of normal cerebrospinal fluid flow-dynamics. Patients with large volume $\mathrm{ICH}$, intracranial mass effect, and coma may benefit from ICP monitoring, though this intervention has not been proved to benefit outcomes after $\mathrm{ICH}[118,119]$. We recommend a stepwise protocol for addressing intracranial hypertension in the ICU setting.

\section{Cerebrospinal fluid drainage}

Initial cerebrospinal fluid drainage may be a life-saving procedure particularly in the setting of hydrocephalus and IVH [67] (Class IIA, Level of Evidence B). This technique allows for rapid clearance of cerebrospinal fluid, release of ICP, and ICP/CPP monitoring. As a general rule, an ICP monitor or external ventricular drain (EVD) should be placed in all comatose $\mathrm{ICH}$ patients (GCS score of 8 or less) with the goal of maintaining ICP less than $20 \mathrm{mmH}_{2} \mathrm{O}$ $(<15 \mathrm{mmHg}$ ) and CPP at greater than $70 \mathrm{mmHg}$, unless their condition is so dismal that aggressive ICU care is not warranted. Compared to parenchymal monitors, EVDs carry the therapeutic advantage of allowing cerebrospinal fluid drainage, and the disadvantage of a substantial risk of infection (approximately 10\% during the first 10 days) [120]. A small retrospective study failed to show any relationship between changes in ventricular size and level of consciousness in ICH patients treated with EVDs [121].

\section{Sedation}

Sedation should be used to minimize pain, agitation, and decrease surges in ICP (Class IIA, Level of Evidence B). Agitation must be avoided, because it can aggravate ICP elevation through straining (increasing thoracic, jugular venous, and systemic $B P$ ), increased cerebral metabolic rate of oxygen, and also may cause uncontrolled hyper-/hypoventilation, which both can be detrimental. During an ICP spike, sedation may be all that is necessary to control the ICP. The goal of sedation should be a calm, comfortable, and cooperative state in patients with ICP that is well-controlled, and a quiet, motionless state in patients where ICP elevation requires active management. The preferred regimen is the combination of a short-acting opioid, such as fentanyl (1 to $3 \mu \mathrm{g} / \mathrm{kg} / \mathrm{h}$ ) or remifentanyl ( 0.03 to $0.25 \mu \mathrm{g} / \mathrm{kg} / \mathrm{minute}$ ), to provide analgesia, and propofol ( 0.3 to $3 \mathrm{mg} / \mathrm{kg} / \mathrm{h}$ ) because of its extremely short half-life, which makes it ideal for periodic interruption for neurological assessments, which should be performed on a daily basis unless the patient has demonstrated that the ICP is too unstable (frequent ICP crisis in the setting of awakening, position changes, fever, and so on) to tolerate this. Bolus injections of opioids should be used with caution in patients with elevated ICP because they can transiently lower MAP and increase ICP due to autoregulatory vasodilation of cerebral vessels [122]. Compared to an opiod-based sedation regimen, in one trial propofol was associated with lower ICP and fewer ICP interventions in patients with severe traumatic brain injury [123]. However, propofol has been associated with mithocondrial dysfunction and multi-organ failure (propofol infusion syndrome). Predisposing factors include young age, severe critical illness of central nervous system or respiratory origin, exogenous catecholamine or glucocorticoid administration, inadequate carbohydrate intake and subclinical mitochondrial disease [124].

\section{Cerebral perfusion pressure optimization}

Two prevailing management strategies for the management of elevated ICP have evolved from the experience in traumatic brain injury. The 'Lund concept' assumes a disruption of the blood brain barrier and recommends manipulations to decrease the hydrostatic BP and increase osmotic pressures to minimize cerebral blood volume and vasogenic edema by improving perfusion and oxygenation to the injured areas of the brain [125]. This is achieved in theory by maintaining an euvolemic state with normal hemoglobin, hematocrit, plasma protein concentrations, and by antagonizing vasoconstriction through reduction of catecholamine concentration in plasma and sympathetic outflow. These therapeutic measures attempt to normalize all essential hemodynamic parameters (blood 
pressure, plasma oncotic pressure, plasma and erythrocyte volumes, arterial partial pressure of oxygen $\left(\mathrm{PaO}_{2}\right)$, and arterial partial pressure of carbon dioxide $\left.\left(\mathrm{PaCO}_{2}\right)\right)$. The introduction of microdialysis with novel physiological targets may optimize the goals of the original Lund protocol. The 'Rosner concept' emphasizes maintaining a high CPP to minimize reflex vasodilatation or ischemia [126,127] at the expense of added cardiopulmonary stress (Class IIA, Level of Evidence B). Computerized bedside graphical displays (ICU Pilot $^{\circledR}$, CMA Micodialysis, Solna, Sweden) can allow clinicians to identify whether ICP and MAP are positively correlated, in which case a low CPP would be preferable, or negatively correlated, in which case a higher CPP would be desirable.

\section{Hyperosmolar therapy}

Hyperosmolar therapy [128] should be used after sedation and CPP optimization fail to normalize ICP (Class IIA, Level of Evidence B). The initial dose of mannitol is 1 to $1.5 \mathrm{~g} / \mathrm{kg}$ of a $20 \%$ solution, followed by bolus doses of 0.25 to $1.0 \mathrm{~g} / \mathrm{kg}$ as needed to a target osmolality of 300 to $320 \mathrm{mOsm} / \mathrm{kg}$. Additional doses can be given as frequently as once an hour, based on the initial response to therapy with the anticipation of a transient drop in BP. There is little to recommend the use of standing mannitol in patients with normal ICP. In a recent trial of mannitol for $\mathrm{ICH}, 128$ patients were randomized to receive low-dose mannitol ( $100 \mathrm{ml}$ of $20 \%$ solution) or sham therapy every 4 hours for 5 days with a rapid dose tapering schedule over 48 hours. The 1 -month mortality rate was $25 \%$ in both groups and disability scores at 3 months were not significantly different between groups [129]. Hypertonic saline, such as $23.4 \%$ saline solution, can be used as an alternative to mannitol, particularly when CPP augmentation is desirable (Class IIA, Level of Evidence B). However, care should be taken to avoid fluid overload in the setting of heart or kidney failure. Additional side effects of hyperosmolar therapy include kidney failure, rebound ICP, electrolytic imbalance (hypo-/hyper-natremia), and acid/base disturbances. Despite clinical and animal model support [64], many issues remain to be clarified, including the exact mechanism of action, best mode and timing of administration, and the most appropriate concentration.

\section{Hyperventilation}

Forced hyperventilation is generally used sparingly in the ICU and, for brief periods, in monitored patients, because its effect on ICP tends to last for only a few hours (Class IIA, Level of Evidence B). Good long term outcomes can occur when the combination of osmotherapy and hyperventilation is successfully used to reverse transtentorial herniation [130]. Overly aggressive hyperventilation to $\mathrm{pCO}_{2}$ levels $<25 \mathrm{mmHg}$ may cause excessive vasoconstriction and exacerbation of ischemia during the acute phase of $\mathrm{ICH}$ and should be avoided. Controlled hyperventilation therapy can be optimized by saturation of jugular vein oxygen and partial brain tissue oxygenation monitoring.

\section{Barbiturates}

For cases of severe and intractable intracranial hypertension, barbiturates can control ICP by decreasing cerebral metabolic activity, which translates into a reduction of the $\mathrm{CBF}$ and cerebral blood volume (Class IIB, level of Evidence B). Pentobarbital can be given in repeated $5 \mathrm{mg} / \mathrm{kg}$ boluses every 15 to 30 minutes until ICP is controlled (usually 10 to $20 \mathrm{mg} / \mathrm{kg}$ is required), and then continuously infused at 1 to $4 \mathrm{mg} / \mathrm{kg} / \mathrm{h}$. An electroencephalogram should be continuously recorded, and the pentobarbital titrated to produce a burstsuppression pattern, with approximately 6 to 8 second interbursts, to avoid excessive sedation.

\section{Hypothermia}

If pentobarbital fails to control ICP, induced hypothermia to 32 to $34^{\circ} \mathrm{C}$ can effectively lower otherwise refractory ICP (Class IIB, Level of Evidence C) [131]. Hypothermia can be achieved using various surface and endovascular cooling systems coupled to a rectal, esophageal, pulmonary artery, or bladder thermometer. Complications of hypothermia include nosocomial infection, hypotension, cardiac arrhythmias, coagulopathy, shivering, hyperkalemia, hyperglycemia, and ileus. Because these risks increase with the depth and duration of cooling, some advocate for the induction of mild hypothermia $\left(34\right.$ to $36^{\circ} \mathrm{C}$ ) if temperature reduction is required for a prolonged period of time to control ICP [104,132,133].

\section{Intraventricular thrombolytic therapy}

$\mathrm{IVH}$ commonly results from extension of $\mathrm{ICH}$ into the cerebral ventricular system, and is an independent predictor of mortality after ICH [134]. Commonly, hydrocephalus and IVH are managed with an EVD, but outcomes remain poor [9]. Intraventricular administration of the plasminogen activator urokinase every 12 hours may reduce hematoma size and the expected mortality rate at 1 month [135]. Several small studies have reported the successful use of urokinase or tissue plasminogen activator ( $\mathrm{t}-\mathrm{PA}$ ) for the treatment of $\mathrm{IVH}$, with the goal of accelerating the clearance of $\mathrm{IVH}$ and improving clinical outcome [136]. A Cochrane systematic review published in 2002 summarized the experience of several case series providing evidence of safety but no definitive efficacy [137]. No randomized prospective controlled trial has addressed the efficacy of intraventricular thrombolysis after $\mathrm{ICH}$. The ongoing Clear IVH Trial (Clot Lysis Evaluating Accelerated Resoution of Intra Ventricular Hemorrhage), a phase II multicenter study evaluating recombinant t-PA treatment of patients with IVH, is designed to investigate the optimum dose and frequency of recombinant t-PA administered via an intraventricular catheter to safely and effectively treat IVH and will soon provide some insight into this issue [138]. When used off-label, a dose of $1 \mathrm{mg}$ of t-PA every 8 hours (followed by clamping of the EVD for 1 hour) is reasonable until clearance of blood from the third ventricle has been achieved [139]. Doses of $3 \mathrm{mg}$ or more of t-PA for IVH thrombolysis have been associated with an unacceptably high bleeding rate (Daniel Hanley, MD, personal communication). 


\section{Deep venous thrombosis prophylaxis}

Patients with $\mathrm{ICH}$ are at high risk for deep vein thrombosis and pulmonary embolism, a potentially fatal complication, due to limb paresis and prolonged immobilization. Dynamic compression stockings should be placed on admission [140] (Class I, Level of Evidence B). A small prospective trial has shown that low dose subcutaneous heparin (5000 U BID) starting after the second day significantly reduces the frequency of venous thromboembolism, with no increase in intracranial bleeding (Class IIB, Level of Evidence B) [141]. Treatment with low molecular weight heparin (enoxaparin $40 \mathrm{mg}$ daily) is a reasonable alternative if renal function is normal (Class IIB, Level of Evidence C).

\section{Nutrition}

As is the case with all critically ill neurological patients, enteral feeding should be started within 48 hours to avoid protein catabolism and malnutrition. A small-bore nasoduodenal feeding tube may reduce the risk of aspiration events.

\section{Surgical intervention for intracerebral hemorrhage}

Craniotomy has been the most studied intervention for the surgical management of $\mathrm{ICH}$ but the results have been discouraging. Two earlier smaller trials showed that for patients presenting with moderate alterations in the state of consciousness, surgery reduced the risk of death without improving the functional outcome [142] and that ultra-early evacuation might improve the 3-month NIHSS [143]. Nevertheless, in a metaanalysis of all prior trials of surgical intervention for supratentorial $\mathrm{ICH}$, no benefit was demonstrated [144].

The International Surgical Trial in Intracerebral Haemorrhage (STICH) study, a landmark trial of over 1,000 ICH patients, showed that emergent surgical hematoma evacuation via craniotomy within 72 hours of onset fails to improve outcome compared to a policy of initial medical management [145]. Although the STICH has rightfully dampened the enthusiasm of neurosurgeons for performing surgery, it must be remembered that the trial was based on the principle of clinical equipoise and patients who the local investigator felt would most likely benefit from emergency surgery were not enrolled into the study. In a post hoc analysis of the STICH, the subgroup of patients with superficial hematomas and no IVH had better outcomes in the surgical arm [146]. This observation provided support for the STICH-II, which is currently enrolling patients [147]. In contrast to supratentorial $\mathrm{ICH}$, there is much better evidence that cerebellar hemorrhages exceeding $3 \mathrm{~cm}$ in diameter benefit from emergent surgical evacuation as abrupt and dramatic deterioration to coma can occur within the first 24 hours of onset in these patients (Class I, Level of evidence B) [148]. For this reason, it is generally unwise to defer surgery in these patients until further clinical deterioration occurs.

As emergent craniotomy has been unable to improve neurological outcome after $\mathrm{ICH}$, the role of other surgical techniques such as minimally invasive surgery have gained importance over the past decade. The advantages of minimally invasive surgery over conventional craniotomy include reduced operative time, the possibility of performance under local anesthesia, and reduced surgical trauma. Endoscopic aspiration of supratentorial $\mathrm{ICH}$ was studied in a small single-center randomized controlled trial (Class IIB, Level of Evidence B) [149]. The study showed that this technique provided a reduction of mortality rate at 6 months in the surgical group but surgery was more effective in superficial hematomas and in younger patients ( $<60$ years).

Thrombolytic therapy and surgical removal of hematomas is another technique that has been studied in a single center randomized clinical trial (Class IIB, Level of Evidence B) [143]. Patients in the surgical group had better outcome scores than the medically treated group. Finally, a multicenter randomized control trial examined the utility of sterotactic urokinase infusion when administered within 72 hours to patients with GCS score $\geq 5$ and hematomas $\geq 10 \mathrm{ml}$ [150]; this provided significant reduction in hematoma size and mortality rate at the expense of higher rates of rebleeding but no significant differences in outcomes measures was seen.

Hemicraniectomy with duraplasty has been proposed as a life-saving intervention for several neurological catastrophes, such as malignant middle cerebral artery infarction and poor grade subarachnoid hemorrhage. No randomized controlled trial has been conducted in patients with $\mathrm{ICH}$. In a recent report of 12 consecutive patients with hypertensive $\mathrm{ICH}$ and treated with hemicraniectomy, 11 (92\%) survived at discharge and 6 of them (54.5\%) had a good functional outcome (modified Rankin Score 0 to 3) [151]. These preliminary data support the need for better controlled studies addressing the role of this surgical technique in $\mathrm{ICH}$ patients (Class IIB, Level of Evidence B).

\section{Conclusions}

Despite a long history of devastating outcomes and high mortality, there is optimism that the management of $\mathrm{ICH}$ will change in the future based on new insights into the acute pathophysiology of this disease. A better understanding of the dynamic process of hematoma growth, importance of inflammation triggered by coagulation and products of blood degradation, and the deleterious effects of fever and hyperglycemia may provide feasible targets for future interventions. A recent setback in the form of a negative phase III trial evaluating ultra-early hemostatic therapy with rFVIla for acute $\mathrm{ICH}$ has led researchers to investigate CT angiography as a method for identifying patients with contrast extravasation and an increased risk of active bleeding. Other promising approaches that deserve further study include thrombolytic therapy for IVH [138], minimally invasive surgery for clot lysis [152], and the development of novel antiinflammatory agents that target coagulation-induced peri- 
This article is part of a review series on Stroke, edited by David Menon.

Other articles in the series can be found online at http://ccforum.com/series/CC_Stroke

hematomal brain injury, such as thrombin, hemoglobin, matrix metalloproteinases, and vascular endothelial growth factor [153]. These advances will hopefully lead to new optimism for what has historically been one of the most devastating illnesses in clinical medicine, and establish $\mathrm{ICH}$ as a medically treatable condition worthy of aggressive ICU support.

\section{Competing interests}

SAM has received research grant support, unrestricted educational grants, consulting fees, and speaking honoraria from Novo Nordisk A/S; and unrestricted educational grants, consulting fees, speaking honoraria from PDL BioPharma and EKR therapeutics. FR has no potential conflicts of interest to report.

\section{References}

1. Sacco RL, Mayer SA: Epidemiology of intracerebral hemorrhage. In Intracerebral Hemorrhage. Edited by Feldmann E. Armonk, NY: Futura Publishing Co.; 1994:3-23.

2. Broderick J, Connolly S, Feldmann E, Hanley D, Kase C, Krieger D, Mayberg M, Morgenstern L, Ogilvy CS, Vespa P, Zuccarello M; American Heart Association; American Stroke Association Stroke Council; High Blood Pressure Research Council; Quality of Care and Outcomes in Research Interdisciplinary Working Group: Guidelines for the management of spontaneous intracerebral hemorrhage in adults: 2007 update: a guideline from the American Heart Association/American Stroke Association Stroke Council, High Blood Pressure Research Council, and the Quality of Care and Outcomes in Research Interdisciplinary Working Group. Stroke 2007, 38:2001-2023.

3. Gebel JM, Broderick JP: Intracerebral hemorrhage. Neurol Clin 2000, 18:419-438.

4. Holloway RG, Witter DM Jr, Lawton KB, Lipscomb J, Samsa G: Inpatient costs of specific cerebrovascular events at five academic medical centers. Neurology 1996, 46:854-860.

5. Taylor TN, Davis PH, Torner JC, Holmes J, Meyer JW, Jacobson MF: Lifetime cost of stroke in the United States. Stroke 1996, 27:1459-1466.

6. Qureshi Al, Tuhrim S, Broderick JP, Batjer HH, Hondo H, Hanley DF: Spontaneous intracerebral hemorrhage. $N$ Engl J Med 2001, 344:1450-1460.

7. Skidmore CT, Andrefsky J: Spontaneous intracerebral hemorrhage: epidemiology, pathophysiology, and medical management. Neurosurg Clin N Am 2002, 13:281-288, v.

8. Siddique MS, Gregson BA, Fernandes HM, Barnes J, Treadwell L, Wooldridge TD, Mendelow AD: Comparative study of traumatic and spontaneous intracerebral hemorrhage. J Neurosurg 2002, 96:86-89.

9. Mayer SA, Rincon F: Treatment of intracerebral haemorrhage. Lancet Neurol 2005, 4:662-672.

10. Measuring and improving quality of care: a report from the American Heart Association/American College of Cardiology First Scientific Forum on Assessment of Healthcare Quality in Cardiovascular Disease and Stroke. Circulation 2000, 101: 1483-1493.

11. Brott $\mathrm{T}$, Thalinger $\mathrm{K}$, Hertzberg V: Hypertension as a risk factor for spontaneous intracerebral hemorrhage. Stroke 1986, 17: 1078-1083.
12. Thrift AG, McNeil JJ, Forbes A, Donnan GA: Three important subgroups of hypertensive persons at greater risk of intracerebral hemorrhage. Melbourne Risk Factor Study Group. Hypertension 1998, 31:1223-1229.

13. Fisher C: Pathological observations in hypertensive intracerebral hemorrhage. J Neuropathol Exp Neurol 1971, 30:536-550.

14. Kase CS, Williams JP, Wyatt DA, Mohr JP: Lobar intracerebral hematomas: clinical and CT analysis of 22 cases. Neurology 1982, 32:1146-1150

15. Segal AZ, Chiu RI, Eggleston-Sexton PM, Beiser A, Greenberg SM: Low cholesterol as a risk factor for primary intracerebral hemorrhage: A case-control study. Neuroepidemiology 1999, 18:185-193.

16. Iso $\mathrm{H}$, Jacobs DR Jr, Wentworth D, Neaton JD, Cohen JD: Serum cholesterol levels and six-year mortality from stroke in 350,977 men screened for the multiple risk factor intervention trial. N Engl J Med 1989, 320:904-910.

17. Yano K, Reed DM, MacLean CJ: Serum cholesterol and hemorrhagic stroke in the Honolulu Heart Program. Stroke 1989, 20: 1460-1465.

18. Iribarren C, Jacobs DR, Sadler M, Claxton AJ, Sidney S: Low total serum cholesterol and intracerebral hemorrhagic stroke: is the association confined to elderly men? The Kaiser Permanente Medical Care Program. Stroke 1996, 27:1993-1998.

19. Plehn JF, Davis BR, Sacks FM, Rouleau JL, Pfeffer MA, Bernstein V, Cuddy TE, Moyé LA, Piller LB, Rutherford J, Simpson LM, Braunwald E: Reduction of stroke incidence after myocardial infarction with pravastatin: the Cholesterol and Recurrent Events (CARE) study. The Care Investigators. Circulation 1999, 99:216-223.

20. Amarenco P, Bogousslavsky J, Callahan A 3rd, Goldstein LB, Hennerici M, Rudolph AE, Sillesen H, Simunovic L, Szarek M, Welch KM, Zivin JA; Stroke Prevention by Aggressive Reduction in Cholesterol Levels (SPARCL) Investigators: High-dose atorvastatin after stroke or transient ischemic attack. $N$ Engl J Med 2006, 355:549-559.

21. Gill JS, Shipley MJ, Tsementzis SA, Hornby RS, Gill SK, Hitchcock ER, Beevers DG: Alcohol consumption - a risk factor for hemorrhagic and non-hemorrhagic stroke. Am J Med 1991, 90:489-497.

22. Gill JS, Zezulka AV, Shipley MJ, Gill SK, Beevers DG: Stroke and alcohol consumption. N Engl J Med 1986, 315:1041-1046.

23. Gorelick PB: Alcohol and stroke. Stroke 1987, 18:268-271.

24. Klatsky AL, Armstrong MA, Friedman GD: Alcohol use and subsequent cerebrovascular disease hospitalizations. Stroke 1989, 20:741-746.

25. Thrift AG, Donnan GA, McNeil JJ: Heavy drinking, but not moderate or intermediate drinking, increases the risk of intracerebral hemorrhage. Epidemiology 1999, 10:307-312.

26. Levine SR, Brust JC, Futrell N, Ho KL, Blake D, Millikan CH, Brass LM, Fayad P, Schultz LR, Selwa JF, et al:: Cerebrovascular complications of the use of the "crack" form of alkaloidal cocaine. N Engl J Med 1990, 323:699-704.

27. Ariesen MJ, Claus SP, Rinkel GJ, Algra A: Risk factors for intracerebral hemorrhage in the general population: a systematic review. Stroke 2003, 34:2060-2065.

28. Qureshi Al, Mohammad $\mathrm{Y}$, Suri MF, Braimah J, Janardhan V, Guterman LR, Hopkins LN, Frankel MR: Cocaine use and hypertension are major risk factors for intracerebral hemorrhage in young African Americans. Ethn Dis 2001, 11:311-319.

29. Arboix A, Vall-Llosera A, Garcia-Eroles L, Massons J, Oliveres M, Targa C: Clinical features and functional outcome of intracerebral hemorrhage in patients aged 85 and older. $J \mathrm{Am}$ Geriatr Soc 2002, 50:449-454.

30. Daverat P, Castel JP, Dartigues JF, Orgogozo JM: Death and functional outcome after spontaneous intracerebral hemorrhage. A prospective study of 166 cases using multivariate analysis. Stroke 1991, 22:1-6.

31. Broderick JP, Brott T, Tomsick T, Miller R, Huster G: Intracerebral hemorrhage more than twice as common as subarachnoid hemorrhage. J Neurosurg 1993, 78:188-191.

32. Kothari RU, Brott T, Broderick JP, Barsan WG, Sauerbeck LR, Zuccarello M, Khoury J: The ABCs of measuring intracerebral hemorrhage volumes. Stroke 1996, 27:1304-1305.

33. Newman GC: Clarification of abc/2 rule for ICH volume. Stroke 2007, 38:862.

34. Becker KJ, Baxter AB, Bybee HM, Tirschwell DL, Abouelsaad T, 
Cohen WA: Extravasation of radiographic contrast is an independent predictor of death in primary intracerebral hemorrhage. Stroke 1999, 30:2025-2032.

35. Goldstein JN, Fazen LE, Snider R, Schwab K, Greenberg SM, Smith EE, Lev MH, Rosand J: Contrast extravasation on CT angiography predicts hematoma expansion in intracerebral hemorrhage. Neurology 2007, 68:889-894.

36. Wada R, Aviv RI, Fox AJ, Sahlas DJ, Gladstone DJ, Tomlinson G, Symons SP: CT angiography "spot sign" predicts hematoma expansion in acute intracerebral hemorrhage. Stroke 2007, 38:1257-1262.

37. Kidwell CS, Chalela JA, Saver JL, Starkman S, Hill MD, Demchuk AM, Butman JA, Patronas N, Alger JR, Latour LL, Luby ML, Baird AE, Leary MC, Tremwel M, Ovbiagele B, Fredieu A, Suzuki S, Villablanca JP, Davis S, Dunn B, Todd JW, Ezzeddine MA, Haymore J, Lynch JK, Davis L, Warach S: Comparison of MRI and CT for detection of acute intracerebral hemorrhage. JAMA 2004, 292:1823-1830

38. Zhu XL, Chan MS, Poon WS: Spontaneous intracranial hemorrhage: which patients need diagnostic cerebral angiography? A prospective study of 206 cases and review of the literature. Stroke 1997, 28:1406-1409.

39. Halpin SF, Britton JA, Byrne JV, Clifton A, Hart G, Moore A: Prospective evaluation of cerebral angiography and computed tomography in cerebral haematoma. J Neurol Neurosurg Psychiatry 1994, 57:1180-1186.

40. Gujjar AR, Deibert E, Manno EM, Duff S, Diringer MN: Mechanical ventilation for ischemic stroke and intracerebral hemorrhage: indications, timing, and outcome. Neurology 1998, 51: 447-451.

41. Diringer MN: Intracerebral hemorrhage: pathophysiology and management. Crit Care Med 1993, 21:152-157.

42. Reynolds SF, Heffner J: Airway management of the critically ill patient: rapid-sequence intubation. Chest 2005, 127:13971412.

43. Fellows IW, Bastow MD, Byrne AJ, Allison SP: Adrenocortical suppression in multiply injured patients: a complication of etomidate treatment. Br Med J (Clin Res Ed) 1983, 287:18351837.

44. Papazian L, Albanese J, Thirion X, Perrin G, Durbec O, Martin C: Effect of bolus doses of midazolam on intracranial pressure and cerebral perfusion pressure in patients with severe head injury. Br J Anaesth 1993, 71:267-271.

45. Orebaugh SL: Succinylcholine: adverse effects and alternatives in emergency medicine. Am J Emerg Med 1999, 17:715721.

46. Booij LH: Is succinylcholine appropriate or obsolete in the intensive care unit? Crit Care 2001, 5:245-246.

47. Schramm WM, Jesenko R, Bartunek A, Gilly H: Effects of cisatracurium on cerebral and cardiovascular hemodynamics in patients with severe brain injury. Acta Anaesthesiol Scand 1997, 41:1319-1323.

48. Schramm WM, Strasser K, Bartunek A, Gilly H, Spiss CK: Effects of rocuronium and vecuronium on intracranial pressure, mean arterial pressure and heart rate in neurosurgical patients. $\mathrm{Br} J$ Anaesth 1996, 77:607-611.

49. Robinson N, Clancy M: In patients with head injury undergoing rapid sequence intubation, does pretreatment with intravenous lignocaine/lidocaine lead to an improved neurological outcome? A review of the literature. Emerg Med J 2001, 18: 453-457.

50. Passero S, Ciacci G, Ulivelli M: The influence of diabetes and hyperglycemia on clinical course after intracerebral hemorrhage. Neurology 2003, 61:1351-1356.

51. Siddique MS, Fernandes HM, Wooldridge TD, Fenwick JD, Slomka P, Mendelow AD: Reversible ischemia around intracerebral hemorrhage: a single-photon emission computerized tomography study. J Neurosurg 2002, 96:736-741.

52. Rosand J, Eskey C, Chang Y, Gonzalez RG, Greenberg SM, Koroshetz WJ: Dynamic single-section CT demonstrates reduced cerebral blood flow in acute intracerebral hemorrhage. Cerebrovasc Dis 2002, 14:214-220.

53. Brott T, Broderick J, Kothari R, Barsan W, Tomsick T, Sauerbeck L, Spilker J, Duldner J, Khoury J: Early hemorrhage growth in patients with intracerebral hemorrhage. Stroke 1997, 28:1-5.

54. Broderick JP, Diringer MN, Hill MD, Brun NC, Mayer SA, Steiner $\mathrm{T}$, Skolnick BE, Davis SM: Determinants of intracerebral hemorrhage growth: an exploratory analysis. Stroke 2007, 38: 1072-1075.

55. Powers WJ, Zazulia AR, Videen TO, Adams RE, Yundt KD, Aiyagari V, Grubb RL Jr, Diringer MN: Autoregulation of cerebral blood flow surrounding acute ( 6 to 22 hours) intracerebral hemorrhage. Neurology 2001, 57:18-24.

56. Powers WJ, Adams RE, Yundt KD: Acute pharmacological hypotension after intracerebral hemorrhage does not change cerebral blood flow. Stroke 1999, 30:242.

57. Qureshi Al, Wilson DA, Hanley DF, Traystman RJ: Pharmacologic reduction of mean arterial pressure does not adversely affect regional cerebral blood flow and intracranial pressure in experimental intracerebral hemorrhage. Crit Care Med 1999, 27:965-971.

58. Rose JC, Mayer SA: Optimizing blood pressure in neurological emergencies. Neurocritical Care 2004, 1:287-299.

59. Kuwata N, Kuroda K, Funayama M, Sato N, Kubo N, Ogawa A: Dysautoregulation in patients with hypertensive intracerebral hemorrhage. A SPECT study. Neurosurg Rev 1995, 18:237245.

60. Mayer SA, Lignelli A, Fink ME, Kessler DB, Thomas CE, Swarup $\mathrm{R}$, Van Heertum RL: Perilesional blood flow and edema formation in acute intracerebral hemorrhage: a SPECT study. Stroke 1998, 29:1 1791-1798.

61. Lang EW, Lagopoulos J, Griffith J, Yip K, Mudaliar Y, Mehdorn HM, Dorsch NW: Noninvasive cerebrovascular autoregulation assessment in traumatic brain injury: validation and utility. $J$ Neurotrauma 2003, 20:69-75.

62. Antihypertensive Treatment in Acute Cerebral Hemorrhage [http://www.strokecenter.org/trials/TrialDetail.aspx?tid=602]

63. Intensive Blood Pressure Reduction in Acute Cerebral Haemorrhage [http://www.clinicaltrials.gov/ct/show/ NCT00226096?order=1]

64. Qureshi Al, Wilson DA, Traystman RJ: Treatment of transtentorial herniation unresponsive to hyperventilation using hypertonic saline in dogs: effect on cerebral blood flow and metabolism. J Neurosurg Anesthesiol 2002, 14:22-30.

65. Poungvarin $N$, Bhoopat $W$, Viriyavejakul A, Rodprasert $P$ Buranasiri P, Sukondhabhant S, Hensley MJ, Strom BL: Effects of dexamethasone in primary supratentorial intracerebral hemorrhage. N Engl J Med 1987, 316:1229-1233.

66. Tellez $\mathrm{H}$, Bauer RB: Dexamethasone as treatment in cerebrovascular disease. 1. A controlled study in intracerebral hemorrhage. Stroke 1973, 4:541-546.

67. Liliang PC, Liang CL, Lu CH, Chang HW, Cheng $\mathrm{CH}$, Lee TC, Chen $\mathrm{HJ}$ : Hypertensive caudate hemorrhage prognostic predictor, outcome, and role of external ventricular drainage. Stroke 2001, 32:1195-1200.

68. Fujii Y, Takeuchi S, Sasaki O, Minakawa T, Tanaka R: Multivariate analysis of predictors of hematoma enlargement in spontaneous intracerebral hemorrhage. Stroke 1998, 29:1160-1166.

69. Fujii $Y$, Tanaka R, Takeuchi S, Koike T, Minakawa T, Sasaki O: Hematoma enlargement in spontaneous intracerebral hemorrhage. J Neurosurg 1994, 80:51-57

70. Kazui S, Naritomi H, Yamamoto H, Sawada T, Yamaguchi T: Enlargement of spontaneous intracerebral hemorrhage. Incidence and time course. Stroke 1996, 27:1783-1787.

71. Mayer SA, Brun NC, Begtrup K, Broderick J, Davis S, Diringer MN, Skolnick BE, Steiner T: Recombinant activated factor VII for acute intracerebral hemorrhage. N Engl J Med 2005, 352: 777-785.

72. Piriyawat $P$ ML, Yawn DH, Hall CE, Grotta JC: Treatment of Acute Intracerebral Hemorrhage with epsilon aminocaproic Acid: a pilot study. Neurocritical Care 2004, 1:47-51.

73. Mayer SA, Brun NC, Begtrup K, Broderick J, Davis S, Diringer $\mathrm{MN}$, Skolnick BE, Steiner T: Efficacy and safety of recombinant activated factor VII for acute intracerebral hemorrhage. N Engl $J$ Med 2008, 358:2127-2137.

74. Wintzen AR, de Jonge $H$, Loeliger EA, Bots GT: The risk of intracerebral hemorrhage during oral anticoagulant therapy: a population study. Ann Neurol 1984, 16:553-558.

75. Hart RG, Boop BS, Anderson DC: Oral anticoagulants and intracranial hemorrhage. Facts and hypotheses. Stroke 1995 26:1471-1477

76. Fredriksson K, Norrving B, Stromblad LG: Emergency reversal of anticoagulation after intracerebral hemorrhage. Stroke 1992, 23:972-977. 
77. Makris M, Greaves M, Phillips WS, Kitchen S, Rosendaal FR, Preston EF: Emergency oral anticoagulant reversal: the relative efficacy of infusions of fresh frozen plasma and clotting factor concentrate on correction of the coagulopathy. Thromb Haemost 1997, 77:477-480.

78. Yasaka M, Sakata T, Minematsu K, Naritomi H: Correction of INR by prothrombin complex concentrate and vitamin $K$ in patients with warfarin related hemorrhagic complication. Thromb Res 2002, 108:25-30.

79. Heit JA: Perioperative management of the chronically anticoagulated patient. J Thromb Thrombolysis 2001, 12:81-87.

80. Sorensen B, Johansen P, Nielsen GL, Sorensen JC, Ingerslev J: Reversal of the International Normalized Ratio with recombinant activated factor VII in central nervous system bleeding during warfarin thromboprophylaxis: clinical and biochemical aspects. Blood Coagul Fibrinolysis 2003, 14:469-477.

81. Erhardtsen $E$, Nony $P$, Dechavanne $M$, Ffrench $P$, Boissel JP, Hedner U: The effect of recombinant factor VIla (NovoSeven) in healthy volunteers receiving acenocoumarol to an International Normalized Ratio above 2.0. Blood Coagul Fibrinolysis 1998, 9:741-748.

82. Freeman WD, Brott TG, Barrett KM, Castillo PR, Deen HG Jr, Czervionke LF, Meschia JF: Recombinant factor VIla for rapid reversal of warfarin anticoagulation in acute intracranial hemorrhage. Mayo Clin Proc 2004, 79:1495-1500.

83. Wakefield TW, Stanley JC: Intraoperative heparin anticoagulation and its reversal. Semin Vasc Surg 1996, 9:296-302.

84. Mannucci PM, Remuzzi G, Pusineri F, Lombardi R, Valsecchi C, Mecca G, Zimmerman TS: Deamino-8-D-arginine vasopressin shortens the bleeding time in uremia. N Engl J Med 1983, 308:8-12.

85. Ananthasubramaniam K, Beattie JN, Rosman HS, Jayam V, Borzak S: How safely and for how long can warfarin therapy be withheld in prosthetic heart valve patients hospitalized with a major hemorrhage? Chest 2001, 119:478-484.

86. Mayer SA, Sacco RL, Shi T, Mohr JP: Neurologic deterioration in noncomatose patients with supratentorial intracerebral hemorrhage. Neurology 1994, 44:1379-1384.

87. Mayer SA, Chong J: Critical care management of increased intracranial pressure. J Intensive Care Med 2002, 17:55-67.

88. Diringer MN, Edwards DF: Admission to a neurologic/neurosurgical intensive care unit is associated with reduced mortality rate after intracerebral hemorrhage. Crit Care Med 2001, 29:635-640.

89. Mirski MA, Chang CW, Cowan R: Impact of a neuroscience intensive care unit on neurosurgical patient outcomes and cost of care: evidence-based support for an intensivistdirected specialty ICU model of care. J Neurosurg Anesthesiol 2001, 13:83-92.

90. Hemphill JC, 3rd, Newman J, Zhao S, Johnston SC: Hospital usage of early do-not-resuscitate orders and outcome after intracerebral hemorrhage. Stroke 2004, 35:1130-1134.

91. Becker KJ, Baxter AB, Cohen WA, Bybee HM, Tirschwell DL, Newell DW, Winn HR, Longstreth WT Jr: Withdrawal of support in intracerebral hemorrhage may lead to self-fulfilling prophecies. Neurology 2001, 56:766-772.

92. Ziai WC, Toung TJ, Bhardwaj A: Hypertonic saline: first-line therapy for cerebral edema? J Neurol Sci 2007, 261:157-166.

93. Adrogue HJ, Madias NE: Hypernatremia. N Engl J Med 2000, 342:1493-1499.

94. Broderick JP, Adams HP Jr, Barsan W, Feinberg W, Feldmann E, Grotta J, Kase C, Krieger D, Mayberg M, Tilley B, Zabramski JM, Zuccarello M: Guidelines for the management of spontaneous intracerebral hemorrhage: A statement for healthcare professionals from a special writing group of the Stroke Council, American Heart Association. Stroke 1999, 30:905-915.

95. Passero S, Rocchi R, Rossi S, Ulivelli M, Vatti G: Seizures after spontaneous supratentorial intracerebral hemorrhage. Epilepsia 2002, 43:1175-1180.

96. Vespa PM, O'Phelan K, Shah M, Mirabelli J, Starkman S, Kidwell C, Saver J, Nuwer MR, Frazee JG, McArthur DA, Martin NA: Acute seizures after intracerebral hemorrhage: A factor in progressive midline shift and outcome. Neurology 2003, 60:14411446.

97. Claassen J, Jetté N, Chum F, Green R, Schmidt M, Choi H, Jirsch J, Frontera JA, Connolly ES, Emerson RG, Mayer SA, Hirsch LJ: Electrographic seizures and periodic discharges after intrac- erebral hemorrhage. Neurology 2007, 25:1356-1365

98. Commichau C, Scarmeas N, Mayer SA: Risk factors for fever in the neurologic intensive care unit. Neurology 2003, 60:837841.

99. Szczudlik A, Turaj W, Slowik A, Strojny J: Hyperthermia is not an independent predictor of greater mortality in patients with primary intracerebral hemorrhage. Med Sci Monit 2002, 8: CR702-707.

100. Baena RC, Busto R, Dietrich WD, Globus MY, Ginsberg MD: Hyperthermia delayed by 24 hours aggravates neuronal damage in rat hippocampus following global ischemia. $\mathrm{Neu}^{-}$ rology 1997, 48:768-773

101. Minamisawa $H$, Smith ML, Siesjo BK: The effect of mild hyperthermia and hypothermia on brain damage following 5, 10, and 15 minutes of forebrain ischemia. Ann Neurol 1990, 28: 26-33.

102. Clasen RA, Pandolfi S, Laing I, Casey D Jr: Experimental study of relation of fever to cerebral edema. $J$ Neurosurg 1974, 41: 576-581.

103. Rossi S, Zanier ER, Mauri I, Columbo A, Stocchetti N: Brain temperature, body core temperature, and intracranial pressure in acute cerebral damage. J Neurol Neurosurg Psychiatry 2001, 71:448-454.

104. Schwab S, Georgiadis D, Berrouschot J, Schellinger PD, Graffagnino C, Mayer SA: Feasibility and safety of moderate hypothermia after massive hemispheric infarction. Stroke 2001, 32:2033-2035.

105. Mayer S, Commichau C, Scarmeas N, Presciutti M, Bates J, Copeland D: Clinical trial of an air-circulating cooling blanket for fever control in critically ill neurologic patients. Neurology 2001, 56:292-298.

106. Diringer MN: Treatment of fever in the neurologic intensive care unit with a catheter-based heat exchange system. Crit Care Med 2004, 32:559-564.

107. Mayer SA, Kowalski RG, Presciutti M, Ostapkovich ND, McGann E, Fitzsimmons BF, Yavagal DR, Du YE, Naidech AM, Janjua NA, Claassen J, Kreiter KT, Parra A, Commichau C: Clinical trial of a novel surface cooling system for fever control in neurocritical care patients. Crit Care Med 2004, 32:2508-2515.

108. Fogelholm R, Murros K, Rissanen A, Avikainen S: Admission blood glucose and short term survival in primary intracerebral haemorrhage: a population based study. J Neurol Neurosurg Psychiatry 2005, 76:349-353.

109. Baird TA, Parsons MW, Phanh T, Butcher KS, Desmond PM, Tress BM, Colman PG, Chambers BR, Davis SM: Persistent poststroke hyperglycemia is independently associated with infarct expansion and worse clinical outcome. Stroke 2003, 34:2208-2214.

110. Capes SE, Hunt D, Malmberg K, Pathak P, Gerstein HC: Stress hyperglycemia and prognosis of stroke in nondiabetic and diabetic patients: a systematic overview. Stroke 2001, 32: 2426-2432.

111. Williams LS, Rotich J, Qi R, Fineberg N, Espay A, Bruno A, Fineberg SE, Tierney WR: Effects of admission hyperglycemia on mortality and costs in acute ischemic stroke. Neurology 2002, 59:67-71.

112. Klip A, Tsakiridis T, Marette A, Ortiz PA: Regulation of expression of glucose transporters by glucose: a review of studies in vivo and in cell cultures. Faseb J 1994, 8:43-53.

113. Van den Berghe G: How does blood glucose control with insulin save lives in intensive care? J Clin Invest 2004, 114: 1187-1195.

114. Langouche L, Van den Berghe G: Glucose metabolism and insulin therapy. Crit Care Clin 2006, 22:119-129, vii.

115. Van den Berghe G, Schoonheydt K, Becx P, Bruyninckx F, Wouters PJ: Insulin therapy protects the central and peripheral nervous system of intensive care patients. Neurology 2005, 64:1348-1353.

116. Nilsson OG, Lindgren A, Brandt $L$, Saveland $H$ : Prediction of death in patients with primary intracerebral hemorrhage: a prospective study of a defined population. J Neurosurg 2002, 97:531-536.

117. Tuhrim S, Horowitz DR, Sacher M, Godbold JH: Volume of ventricular blood is an important determinant of outcome in supratentorial intracerebral hemorrhage. Crit Care Med 1999, 27:617-621.

118. Bowers SA, Marshall LF: Outcome in 200 consecutive cases of 
severe head injury treated in San Diego County: a prospective analysis. Neurosurgery 1980, 6:237-242.

119. Unwin DH, Giller CA, Kopitnik TA: Central nervous system monitoring: what helps, what does not. Surg Clin North Am 1991, 71:733-747.

120. Lozier AP, Sciacca RR, Romagnoli MF, Connolly ES Jr: Ventriculostomy-related infections: a critical review of the literature. Neurosurgery 2002, 51:170-181; discussion 181-172.

121. Adams RE, Diringer $M N$ : Response to external ventricular drainage in spontaneous intracerebral hemorrhage with hydrocephalus. Neurology 1998, 50:519-523.

122. Albanese J, Durbec O, Viviand X, Potie F, Alliez B, Martin C: Sufentanil increases intracranial pressure in patients with head trauma. Anesthesiology 1993, 79:493-497.

123. Kelly DF, Goodale DB, Williams J, Herr DL, Chappell ET, Rosner MJ, Jacobson J, Levy ML, Croce MA, Maniker AH, Fulda GJ, Lovett JV, Mohan O, Narayan RK: Propofol in the treatment of moderate and severe head injury: a randomized, prospective double-blinded pilot trial. J Neurosurg 1999, 90:1042-1052.

124. Kam PC, Cardone D: Propofol infusion syndrome. Anaesthesia 2007, 62:690-701.

125. Lundberg N: Continuous recording and control of ventricular fluid pressure in neurosurgical practice. Acta Psychiatr Scand Supp/ 1960, 36:1-193.

126. Chambers IR, Banister K, Mendelow AD: Intracranial pressure within a developing intracerebral haemorrhage. $\mathrm{Br} J$ Neurosurg 2001, 15:140-141.

127. Fernandes HM, Siddique S, Banister K, Chambers I, Wooldridge T, Gregson B, Mendelow AD: Continuous monitoring of ICP and CPP following $\mathrm{ICH}$ and its relationship to clinical, radiological and surgical parameters. Acta Neurochir Supp/ 2000, 76:463-466.

128. Qureshi Al, Suarez Jl: Use of hypertonic saline solutions in treatment of cerebral edema and intracranial hypertension. Crit Care Med 2000, 28:3301-3313.

129. Misra UK, Kalita J, Ranjan P, Mandal SK: Mannitol in intracerebral hemorrhage: a randomized controlled study. J Neurol Sci 2005, 234:41-45.

130. Qureshi Al, Geocadin RG, Suarez JI, Ulatowski JA: Long-term outcome after medical reversal of transtentorial herniation in patients with supratentorial mass lesions. Crit Care Med 2000, 28:1556-1564.

131. Shiozaki T, Sugimoto H, Taneda M, Yoshida H, Iwai A, Yoshioka T, Sugimoto T: Effect of mild hypothermia on uncontrollable intracranial hypertension after severe head injury. J Neurosurg 1993, 79:363-368.

132. Schwab S, Spranger M, Schwarz S, Hacke W: Barbiturate coma in severe hemispheric stroke: useful or obsolete? Neurology 1997, 48:1608-1613.

133. Rincon F, Mayer SA: Therapeutic hypothermia for brain injury after cardiac arrest. Semin Neuro/ 2006, 26:387-395.

134. Hemphill JC, 3rd, Bonovich DC, Besmertis L, Manley GT, Johnston SC: The ICH score: a simple, reliable grading scale for intracerebral hemorrhage. Stroke 2001, 32:891-897.

135. Naff NJ, Carhuapoma JR, Williams MA, Bhardwaj A, Ulatowski JA, Bederson J, Bullock R, Schmutzhard E, Pfausler B, Keyl PM, Tuhrim S, Hanley DF: Treatment of intraventricular hemorrhage with urokinase : effects on 30-day survival. Stroke 2000, 31: 841-847.

136. Coplin WM, Vinas FC, Agris JM, Buciuc R, Michael DB, Diaz FG, Muizelaar JP: A cohort study of the safety and feasibility of intraventricular urokinase for nonaneurysmal spontaneous intraventricular hemorrhage. Stroke 1998, 29:1573-1579.

137. Lapointe M, Haines S: Fibrinolytic therapy for intraventricular hemorrhage in adults. Cochrane Database Syst Rev 2002:CD003692.

138. Evaluating Accelerated Resolution of Intraventricular Hemorrhage, rt-PA (Cathflo ${ }^{\circledR}$ ) Treatment of Brain Hemorrhage [http://www.strokecenter.org/trials/TrialDetail.aspx?tid=607]

139. Nyquist $P$, Hanley DF: The use of intraventricular thrombolytics in intraventricular hemorrhage. J Neurol Sci 2007, 261:84-88.

140. Geerts WH, Pineo GF, Heit JA, Bergqvist D, Lassen MR, Colwell CW, Ray JG: Prevention of venous thromboembolism: the Seventh ACCP Conference on Antithrombotic and Thrombolytic Therapy. Chest 2004, 126(3 Suppl):338S-400S.

141. Boeer A, Voth E, Henze T, Prange HW: Early heparin therapy in patients with spontaneous intracerebral haemorrhage. $J$
Neurol Neurosurg Psychiatry 1991, 54:466-467.

142. Juvela $S$, Heiskanen $O$, Poranen A, Valtonen $S$, Kuurne $T$, Kaste $M$, Troupp $H$ : The treatment of spontaneous intracerebral hemorrhage. A prospective randomized trial of surgical and conservative treatment. J Neurosurg 1989, 70:755-758.

143. Zuccarello M, Brott T, Derex L, Kothari R, Sauerbeck L, Tew J, Van Loveren H, Yeh HS, Tomsick T, Pancioli A, Khoury J, Broderick J: Early surgical treatment for supratentorial intracerebral hemorrhage: a randomized feasibility study. Stroke 1999, 30:18331839.

144. Fernandes HM, Gregson B, Siddique S, Mendelow AD: Surgery in intracerebral hemorrhage. The uncertainty continues. Stroke 2000, 31:2511-2516.

145. Mendelow AD, Gregson BA, Fernandes HM, Murray GD, Teasdale GM, Hope DT, Karimi A, Shaw MD, Barer DH: Early surgery versus initial conservative treatment in patients with spontaneous supratentorial intracerebral haematomas in the International Surgical Trial in Intracerebral Haemorrhage (STICH): a randomised trial. Lancet 2005, 365:387-397.

146. Bhattathiri PS, Gregson B, Prasad KS, Mendelow AD: Intraventricular hemorrhage and hydrocephalus after spontaneous intracerebral hemorrhage: results from the STICH trial. Acta Neurochir Supp/ 2006, 96:65-68.

147. STICH II Trial [http://www.ncl.ac.uk/stich/]

148. Ott KH, Kase CS, Ojemann RG, Mohr JP: Cerebellar hemorrhage: diagnosis and treatment. A review of $\mathbf{5 6}$ cases. Arch Neurol 1974, 31:160-167.

149. Auer LM, Deinsberger W, Niederkorn K, Gell G, Kleinert R, Schneider G, Holzer P, Bone G, Mokry M, Korner E, et al.: Endoscopic surgery versus medical treatment for spontaneous intracerebral hematoma: a randomized study. J Neurosurg 1989, 70:530-535.

150. Teernstra OP, Evers SM, Lodder J, Leffers $P$, Franke CL, Blaauw G: Stereotactic treatment of intracerebral hematoma by means of a plasminogen activator: a multicenter randomized controlled trial (SICHPA). Stroke 2003, 34:968-974.

151. Murthy JM, Chowdary GV, Murthy TV, Bhasha PS, Naryanan TJ: Decompressive craniectomy with clot evacuation in large hemispheric hypertensive intracerebral hemorrhage. Neurocritical care 2005, 2:258-262.

152. Minimally Invasive Surgery Olus rtPA for Intracerebral Hemorrhage Evacuation (MISTIE) [http://www.strokecenter.org/trials/ TrialDetail.aspx?tid $=690]$

153. Rincon F, Mayer SA: Novel therapies for intracerebral hemorrhage. Curr Opin Crit Care 2004, 10:94-100. 